\title{
TRANSLATION SHIFT IN THE TRANSLATED NOVEL OF \\ “TO KILL A MOCKINGBIRD” BY FEMMY SYAHRIANNI.
}

\author{
*Dian Sukma Lestari \\ **Prof. Dr. Zainuddin, DIP.,TEFL.,M.Hum . \\ **Syamsul Bahri, S.S.,M.Hum.
}

\begin{abstract}
The aim of this study were to find out category shift types used in the translation of novel To Kill A Bird and to describe of how category shift is translated in the novel from English into Indonesian. This study were conducted by using descriptive qualitative method. The data of the study were words, phrases, and clauses in the novel To Kill A Mockingbird which is translated into Indonesian by Femmy Syahrianni. It was found that there were 280 data in the novel from English into Indonesian. The data analysis were taken by listing and bolding. Documentary sheets used as the instrument to collect the data. The data were analyzed based on Miles and Huberman (2014) by condensation which consists of selecting, focusing, simplifying, abstracting and transforming and then data display by using table in order to get easy analyzing the data. The result of this study were (1) there were four types of category shifts found in the novel To Kill a Mockingbird namely; structure shifts (36.78\%), class shift (27.14\%), unit shift (32.5\%) and intra-system shift (3.27\%). (2) The process of category shifts in the translation novel by having modifier-head in source language changed into head-modifier in target language, adverb in source language changed into verb in target language, one unit in source language changed into some units in target language. and plural in source language changed into singular in target language.
\end{abstract}

Keyword: Translation shift, structure, class, unit, intra-system shift,novel.

*Graduate status

** Lecturer status 


\section{INTRODUCTION}

The variety of languages in the world undeniably has obstructed people in doing communication. It happens because every language in this world has its own characteristics in terms of grammatical structure and cultural background. Although the communication problems caused by the difference of grammatical structure and cultural background sometimes can be overcome by doing verbal communication, such as showing gestures, facial expressions, and body languages, it can't be denied that not all utterances can be revealed and understood through this kind of communication. Therefore, the role of translation is required to solve the communication problem of two or more different languages effectively and effeciently.

Translation generally means of transfering meaning of two or more different languages. Larson (1984) states that translation is basically change of form. When it is concerned with speaking a language, it refers to the actual words, phrase, clauses, sentences, and paragraph which are spoken or witten.

Nowadays, the progress of translation has been developed to a better stage, although it still needs to get more developed. Some of translation works come from various desciplines such as science, technology, politic, economy and many more. Literary work which is also one of translation products has been develoved rapidly. However, to create a good translation product is not easy. It needs a long process to understand two languages which have different structure and cultural background. Therefore, some procedures in translation are needed to find the equivalent form in the target language. One of the procedures is making the shift. Generally, shift is a translation procedure that involves replacing the source language elements into the target language element without changing the meaning. Translation shift helps the translator to gets the natural translation. According to Catford (1965), there are two types of shift namely level shift and category shifts. A level shift focuses on the changing of the level from grammar to lexis. It means that the grammar in source language will be changed into lexis when translated in the target language. While 
category shift focuses on all kinds of grammatical changes. The kinds of grammatical changes in category shifts namely; structure shift, which focuses on the change of grammatical structure in source language has different structure in target language for example from modifier + head in source language is changed into head + modifier in target language, class shift which focuses on the change of class in source language has different class in target language for example adverb in source language changed into adjective in target language , unit shift which focuses on the change of unit rank in source language has different unit rank in target language, for example rank phrase in source language changed into word in target language, and intra-system shift which deals with the systematically number from singular in source language is changed into plural in target language.

As one of the phenomenon in translation, the writer is interested in making a further study about translation shift found in the English novel which is translated into Indonesian. Catford classified shift into two types; level shift and category shift. In this research, the researcher will only focus on one of the types of shift, namely category shift which is found in the original novel of To Kill a Mockingbird written by Harper Lee and translated by Femmy Sayahriani. In the translation process of the novel, it can be found that the novel contains some of the kinds category shifts such as structure shift, class shift, unit shift and intra-system shift.

Overall, the study will focus on finding types of category shift in novel of To Kill A Mocking bird and describingthe process of how category shift is translated in novels from English into Indonesian. This kind of this research is expected to improve the quality of the translated novel published in Indonesia.

The objectives of this article are:

1. To find out the types of category shift used in the translation of novel To Kill a Mockingbird from English into Indonesian.

2. To describe the process of how category shift are used in translating the novel To Kill a Mockingbird from English into Indonesian. 


\section{RESEARCH METHOD}

This study were conducted by using descriptivequalitative method. Ary, et all (2002:425) state that the qualitative inquirer deals with the data in the form of words, rather than numbers and statistics. Further, it is explained that managing the large volume of desciptive data generated from interviews, observations, and the collection of documents is an important consideration in qualitative studies.

The data of the study were words, phrases and clauses. While source data of the study were novel of To Kill a Mockingbirdwhich is translated into Indonesian by Femmy Syahrianni which consists of thirty one chapters and 296 pages in Source language and the target language consisted of thirty one chapters and 396 pages.

In analyzing the data, the researcher described it by using the interactive model proposed by Miles and Huberman (2014). They state that this method consists of methodology by namely: data condensation which refers to the process of selecting, focusing, simplifying, abstracting, and/or transforming the data. Then data display, and the last verification/ conlusion drawing. 


\section{RESULT AND DISCUSSION}

\section{A. Types of Category Shifts}

Translation shifts was divided into two major types namely level shift and Category shifts. In this study concerned with Category shifts that consisted of four types namely structure shift, class-shift, unit shift, and intra system shift(Catford,1965)

Table 4.1. The Distribution of the Types of Category Shiftd found in Translation novel of To Kill a Mockingbird.

\begin{tabular}{clcc}
\hline Data & \multicolumn{1}{c}{ Category Shift } & Frequency & Occurance \\
\hline $\mathbf{1}$ & Structure Shifts & 103 & 36.78 \\
\hline 2 & Class Shift & 76 & 27.14 \\
\hline 3 & Unit Shift & 91 & 32.05 \\
\hline 4 & Intra-System Shift & 10 & 3.57 \\
\hline \multicolumn{2}{r}{ Total } & $\mathbf{2 8 0}$ & $\mathbf{1 0 0}$ \\
\hline
\end{tabular}

Based on the table 4.1 above it could be concluded that there were four types of category shift in translating of novel entittledTo Kill A Mockingbird namely structure shift, class shift, unit shift and intra-system shift. From the table above it could be taken the conclusion that in fact, the structure shift was about $36.78 \%$ as the highest percentage of shift type used intranslating of that novel. While the second type as the highest percentage was Unit shift about 32.5\% which used in translating of novel entittled “To Kill a Mockingbird". Then, It followed by class shift which covered about $27.14 \%$ and the last was intra-system shift as the lowest percentage in translating that novel namely about 3.57\%.

\section{B. The Process of Category Shifts}

\section{Structure shift}

Structure shift is a shift occur in grammatical structure such as word, phrase, or clause in translation process.

$\mathrm{SL}:$ My first impulse was to get into my mouth as quickly as possible

TL : Instingpertamakuadalahcepat-cepatmemasukannyakemulut 
Based on the data above, it could be seen that the source language "My first impulse” was translated into Indonesian as target language to be "Instingpertamaku”. Here there was a shift in structural rank. It means that the phrase of "My first impulse” in source language had the structure M-H ( Modifier + Head) changed into Indonesia language which had different pattern namely ( Head + Modifier). And similar with the next sample as below.

$\mathrm{SL}:$ A giantic moon was rising behind Miss Maudin's pecan trees

TL : Bulanraksasasedangnaikdibalikpohonkacang pecan Miss Maudy

From the data above, it was clear that the phrase "A gigantic moon" was translated into Indonesian language as target language changed into "BulanRaksasa". It was caused by the structural pattern from source language such as Modifier + Head while in the target language changed to be "Head + Modifier". And then it was shown with the next data namely.

SL : Our biggest prize appeared four days later

TL : Hadiahterbesar kamimunculempatharikemudian

Based on the sample above it could be concluded that the source language of “Our biggest prize” was transleted into Indonesian language as target language became "Hadiahterbesar kami. It this case, the source language of "Our biggest prize" had the patter form "Modifier + Head" whilethe target language changed into Modifier + Head.

SL : He’s gonna make me some invisible ink

TL :Diamaumembuatkantintatakterlihat

From the sample above. It was shown that the phrase of "invisble ink" from source language was translated to be "tintatakterlihat". It was occured a shift because source langauge in English had the pattern "Modifier + Head". When it came to the target language changed into Modifier + Head..And the last was shown as following.

SL : In my comb, grown men stood outside in the front yard only two reasons. 
TL : Di Maycomb, lelakidewasaberdiri di halamandepansaatbertemu untukduaalasan

Based on the sample data above it was shown that the source language of "grown men" was translated into Indonesian language as target language became "lelakidewasa". There was found of shifting here namely in structural form which the pattern form from English as "Modifier + Head" .while in target language had changed into "Head + Modifier".

\section{Class shift}

Class-shifts occuredwhen a SL item is translated with a TL item which belongs to a differentgrammatical class, i.e. a verb may be translated into a noun.

SL : The class murmured apprehensively

TL :Anak-anaksekelasbergumamcemas

From the sample above the word "apprehensively" was translated into target language became "Cemas". Here there was a shift in translating source language into target language namely the word "apprehensively" which functioned as adverb changed into adjective in target language. It was clear that the shift here occurred in the class form. The next was sample as following.

SL : Stunned, Jem and I loked at each other, then atatticus

TL :Tertegun, akudanJembertukarpandanglalumenatap Atticus

Based on the data above the source language "at" was translated into Indonesian language as target language become "menatap". From the data, it could be seen that "at" in source languge functioned as preposition was changed into verb in target language.

SL : A night mare was upon us

TL :Sebuahmimpiburukmendatangi kami.

From the data above it was clear that the word "Upon" from source language was translated in Indonesian language to be "Medatangi". In this case, the shift 
occurred here namely “upon” in source language as adverb had changed into verb in the target language “Mendatangi”.

The next sample was shown as follow:

SL : But the roses on her hat trembeledindignently.

TL :Tetapibungamawar di topinyabergetarmarah.

Based on the data above the word "Indignently" was translated into Indonesian language to be "Marah". From the sample it could be seen that the shift occured in range class which "indignently" as adverb in source language changed into “marah" as adjective in target language.

The other sample was shown as follow:

SL: Atticus would sweep off his hat, wave gallantly to her.

TL: Atticus membukatopilalumelambaigagahkepadanya.

From the sample above, it is clear that the word "gallantly" was translated into Indonesian language to be "gagah". From the sample it could be seen that there is a shift that occured at range class which "gallantly" as an adverb in source language is changed as adjectibve "gagah” when translated to source language.

The last sample was shown as follow:

SL: “Aw, dry up” he answered drowsily.

TL: “Ah, diamlah” jawabnyamengantuk.

From the data above it could be seen that the word "drowsily" was translated into Indonesian language to be "mengantuk". From the sample it was clear that there is a shift that occured at range class which "drowsily" as an adverb in source language changed into "mengantuk" as verb in target language.

\section{Unit shift}

Unit shift is which in the translation process occur to involve changes at ranks.

SL : It was a source of shame to some members of the family

TL :Itumerupakanaibbagisebagiananggotakeluarga. 
From the data above it was clear that the source language "a source of shame" was translated into Indonesian language as target language to be "aib". Here there wasan occurrancein unit form. It means that the laxem from source language was not translated to be "dari". It was caused in order to the translation product could be acceptable and readable. Othewise from source language consisted of four units became one unit in target language namely “Aib”.

SL :Jemcondescended to take me to school the first day.

TL :Jemmenurunkanderajatnyauntukmembawakukesekolahpadahari

Pertama.

From the data above the source language "condenscended" was translated into Indonesian as target language become "menurunkanderajatnya”. From the translation product, it could be seen that there was a shift in unit form which source language "Condenscended" had one unit became two unit in the target language namely “menurunkanderajatnya”.

SL: And itook it for granted that he kept his temper.

TL: Dan akupercayabahwadiabisamenahanamarahnya.

Based on the data above, it could be seen that the source language "took it for granted" was translated into Indonesian become "percaya" from the translation product, it is clear that there is a shift in unit form from four units in source language changed become one unit when translated into Indonesian as target language.

\section{SL :I beg you pardon, JemLoise}

TL: Maaf, JemLoise.

Based on the sample above the soure language " $i$ beg your pardon" was translated in Indonesia as target language become "maaf”. From the sample above was clear that there is a shift at rank unit in source language to target language which that the unit form from source language "I beg you pardon" consisted of five units changed into one unit in the target language namely "Maaf".

SL: Jem stayed moody and silent for a week. 
TL: jemtetapmurungdantidakbanyakbicaraselamasemingu.

Based on the data above, the word "silent" in source language was translated into Indonesia language as a target language become "tidakbanyakbicara" it was clear that there was an occurence in unit form. It means that the laxem from source language was not translated to be "diam". It was caused in order to the translation product could be acceptable and readable. Othewise from source language consisted of one units became three unit in target language namely "tidakbanyakbicara".

SL : One evening we were privillaged to witness the performance by him which seemed to have been his positively last.

TL :Padasuatu sore kami mendapathakistimewauntukmenyaksikan pertunjukan yang sepertinyamerupakanpertunjukanterakhir.

Based on the data above it could be seen that the word "privillaged" was translated into Indonesian language to be "mendapatkanhakistimewa". In this case, it could be concluded that the unit from source language consisted of one unit underwent a shift namely three units form in target language.

SL: The blood in my legs began to flow again and iraised my head.

TL: Darahdalamkakikumulaimengalirlagidanakumendongak.

From the data above the source language "raised my head" was translated into Indonesian language to be "mendongak". It could be seen that there was a shift at unit rank in source language to target language which the unit form that consisted of three units in source language is changed into one unit when translated into Indonesia as target language.

\section{Intra- System Shifts}

It shifted when a SL and TL are in posses approximately corresponding systems but the translation products do not show the relation in termstothe TL system. For Instance articles the, $a$ andan. 
$\mathrm{SL}: \underline{\text { The trees }}$ were still and mocking bird were silent

TL :Pohondiamdan mocking bird tidakbernyanyi

Based the data above, the article 'the' in the clause The trees were still and mocking bird were silent in SL was translated into "pohon" in TL which did not show the relation between the lexems to target language. In application of shift above perhaps occured shifts in one system to another system which followed with structure shift, unit shift or class shift. 


\section{CONCLUSIONS AND SUGGESTIONS}

\section{A. Conclusions}

Based on the analysis of the data that have been done, the follorwings were the conclusions that could be drawn:

1. From 280 data that consist of word, phrases, and clauses it was found that there were four types of category shifts in the English novel of To Kill A Mockingbird which is translated into Indonesian by Femmy Syahrianny namely; Structure Shift, Unit Shift, Class Shift, and intra-system shift. All these category shifts types has percentage as following; structure shift was about $36.78 \%$ as the highest percentage of shift type used intranslating of that novel. While the second type as the highest percentage was Unit shift about $32.5 \%$ which used in translating of novel entittled "To Kill a Mockingbird". Then, It followed by class shift which covered about $27.14 \%$ and the last was intra-system shift as the lowest percentage in translating that novel namely about 3.57\%.

2. The process of Category shift used in translating of novel To Kill A Mockingbird from English into Indonesian by having modifier + Head from source language changed into Head + Modifier in target language, adverb in source language changed into adjective in target language, preposistion in source language changed into verb in target language, one unit in source language changed into some units in target language, from several unit changed into one unit, and then one laxem in source language was not translated into target langauge so that the translation was readable. And then, the plural form in source language changed into singular in target language. 


\section{B. Suggestions}

In relations to the conclusions, some suggestions are given as following:

1. The student of English departments are deeply expected to probe and learn more about the translation shift in translation studies to enlarge their insight.

2. The translator that focus on literary works are expected to learn more about translation shift, especially category shifts as one of types of shift and also the procedure of translation in order that they can produce the better quality of translated literary works. 


\section{REFERENCE}

Ary, D, Jacobs, L.C, Razavieh, A. 2002. Introduction to Research in Education. New York : Belmont, CA Wadsworth.

Bodgan and Biklen. 1982. Qualitative Research For Education. Toroto: Alyn and Bacon.

Borg,WR and Gall, M.G. 1989. Educational Research: An Introduction [5 ${ }^{\text {th }}$ Edition]. Newyork: Longman.

Catford, J.C. 1965. A Linguistic Theory on Translation. London: Oxford University Press.

Hatim,Basil.2001.Teaching and Researching Translation. England: Pearson Education

Hatim, B. and Munday, J. 2004. Translation: An Advanced Resource Book. USA and Canada: Routledge.

Herman.2014. Category shift in the English Translation of Harry Potter and Philosoper's Stone Movie Subtitle into Indonesia. Journal of Humanities and Social Science.19 (12). 31-38. Retrieved December $2^{\text {nd }} 2015$

Herdani.2014. An Analysis of Category shifts in the English-Indonesian Breaking Dawn Movie Texts. Yogyakarta: Yogyakarta State University. 